University of Nebraska - Lincoln

DigitalCommons@University of Nebraska - Lincoln

Publications from USDA-ARS / UNL Faculty

U.S. Department of Agriculture: Agricultural

Research Service, Lincoln, Nebraska

1997

\title{
Yield of wheat across a subambient carbon dioxide gradient
}

Herman S. Mayeux

USDA-ARS Grassland, Soil and Water Research Laboratory

Hyrum B. Johnson

USDA-ARS Grassland, Soil and Water Research Laboratory

H. Wayne Polley

USDA-ARS Grassland, Soil and Water Research Laboratory, wayne.polley@ars.usda.gov

Stephen R. Malone

University of West Alabama

Follow this and additional works at: https://digitalcommons.unl.edu/usdaarsfacpub

Part of the Agricultural Science Commons

Mayeux, Herman S.; Johnson, Hyrum B.; Polley, H. Wayne; and Malone, Stephen R., "Yield of wheat across a subambient carbon dioxide gradient" (1997). Publications from USDA-ARS / UNL Faculty. 432.

https://digitalcommons.unl.edu/usdaarsfacpub/432

This Article is brought to you for free and open access by the U.S. Department of Agriculture: Agricultural Research Service, Lincoln, Nebraska at DigitalCommons@University of Nebraska - Lincoln. It has been accepted for inclusion in Publications from USDA-ARS / UNL Faculty by an authorized administrator of DigitalCommons@University of Nebraska - Lincoln. 


\title{
Yield of wheat across a subambient carbon dioxide gradient
}

\author{
HERMAN S. MAYEUX,* HYRUM B. JOHNSON, * H. WAYNE POLLEY* \\ and STEPHEN R. MALONE ${ }^{1}$ \\ ${ }^{*}$ Grassland, Soil and Water Research Laboratory, U.S. Department of Agriculture, Agricultural Research Service, 808 E. \\ Blackland Road, Temple, TX 76502, USA, ${ }^{1}$ Department of Biology, University of West Alabama, Livingston, AL 35470, USA.
}

\begin{abstract}
Yields and yield components of two cultivars of day-neutral spring wheat (Triticum aestivum $\mathrm{L}$.) were assessed along a gradient of daytime carbon dioxide $\left(\mathrm{CO}_{2}\right)$ concentrations from about 200 to near $350 \mu \mathrm{mol} \mathrm{CO}_{2}(\mathrm{~mol} \mathrm{air})^{-1}$ in a $38 \mathrm{~m}$-long controlled environment chamber. The range in $\mathrm{CO}_{2}$ concentration studied approximates that of Earth's atmosphere since the last ice age. This $75 \%$ rise in $\mathrm{CO}_{2}$ concentration increased grain yields more than $200 \%$ under well-watered conditions and by $\mathbf{8 0 - 1 5 0 \%}$ when wheat was grown without additions of water during the last half of the 100-day growing season. The $27 \%$ increase in $\mathrm{CO}_{2}$ from the pre-industrial level of 150 years ago $(275 \mu \mathrm{mol}$ $\left.\mathrm{mol}^{-1}\right)$ to near the current concentration $\left(350 \mu \mathrm{mol} \mathrm{mol}^{-1}\right)$ increased grain yields of 'Yaqui 54 ' and 'Seri M82' spring wheats by $55 \%$ and $53 \%$, respectively, under well-watered conditions. Yield increased because of greater numbers of grains per spike, rather than heavier grains or numbers of spikes per plant. Water use increased little with $\mathrm{CO}_{2}$ concentration, resulting in improved water use efficiency as $\mathrm{CO}_{2}$ rose. Data suggest that rising $\mathrm{CO}_{2}$ concentration contributed to the substantial increase in average wheat yields in the U.S. during recent decades.
\end{abstract}

Keywords: drought, historical increase in yield, Seri M82, water use efficiency, Yaqui 54, yield components

Received 20 June 1996; revision accepted 30 September 1996

\section{Introduction}

Atmospheric carbon dioxide $\left(\mathrm{CO}_{2}\right)$ concentration rose from below $200 \mu \mathrm{mol} \mathrm{mol}{ }^{-1}$ during the last Glacial period 30-15 ky вР (Delmas et al. 1980; Neftel et al. 1988) to about $275 \mu \mathrm{mol} \mathrm{mol}{ }^{-1}$ between 15 and $12 \mathrm{ky}$ вр (Neftel et al. 1988). It has risen about $30 \%$, to the current $\approx 360 \mu \mathrm{mol} \mathrm{mol}{ }^{-1}$, since the Industrial Revolution 200 years ago (Bascastow et al. 1985; Friedli et al. 1986; Keeling \& Whorf 1994).

These changes in atmospheric $\mathrm{CO}_{2}$ are small compared to those possible during the next century (Trabalka et al. 1985), but may have significantly influenced plant evolution (Ehleringer et al. 1991) and productivity (Johnson et al. 1993). Per unit increase in $\mathrm{CO}_{2}$, growth of $\mathrm{C} 3$ plants is stimulated more over subambient than elevated concentrations (Baker et al. 1990; Allen et al. 1991). Seed yields of soybean [Glycine max (L.) Merr.] (Allen et al. 1991) and rice [Oryza sativa L.] (Baker et al. 1990), for

Correspondence: Wayne Polley, fax +1/817-770-6561, e-mail polley@brcsun0.tamu.edu example, were about $50 \%$ and $60 \%$ greater, respectively, when plants were grown at today's $\mathrm{CO}_{2}$ concentration than the pre-industrial level. Yields were increased proportionally less, $20-50 \%$, by elevating $\mathrm{CO}_{2}$ by $330 \mu \mathrm{mol}$ $\mathrm{mol}^{-1}$ above the current concentration. Similarly dramatic increases in growth have been reported for other $\mathrm{C}_{3}$ species when $\mathrm{CO}_{2}$ was increased over subambient concentrations (Polley et al. 1992; Dippery et al. 1995). By stimulating plant productivity, rising $\mathrm{CO}_{2}$ may have made possible the widespread domestication of plants at the end of the Pleistocene (Sage 1995). The increase in $\mathrm{CO}_{2}$ concentration during recent decades may have improved harvestable yields of some crops (Gifford 1979).

Growth is usually less responsive to atmospheric $\mathrm{CO}_{2}$ when plants are limited by nutrients, light, or water (Strain 1992), although the relative response of growth to $\mathrm{CO}_{2}$ may be maximal under these conditions. Wheat yield increases less at elevated $\mathrm{CO}_{2}$ concentration, for example, when the availability of water (Gifford 1979; Sionit et al. 1980; Chaudhuri et al. 1990), nitrogen 
(Goudriaan \& de Ruiter 1983), a mixture of nutrients (Sionit et al. 1981a), or light (Gifford 1977) are less than optimal than when these resources are abundant. Low resource levels probably limited the absolute increase in plant growth and harvestable yield as atmospheric $\mathrm{CO}_{2}$ rose, but data at subambient concentrations are few (Gifford 1977).

We report yields of two daylength-neutral cultivars of spring wheat that were grown to maturity across a continuous daytime gradient in $\mathrm{CO}_{2}$ concentration from near the Glacial level $\left(200 \mu \mathrm{mol} \mathrm{mol}^{-1}\right)$ to near the current concentration $\left(350 \mu \mathrm{mol} \mathrm{mol}{ }^{-1}\right)$. Plants were grown with abundant and limited water to determine effects of water availability on the response of this important $\mathrm{C}_{3}$ crop to past changes in $\mathrm{CO}_{2}$ concentration. Low water availability is considered a major limitation on agricultural productivity (Loomis 1983). Data are used to address the possible contribution of rising $\mathrm{CO}_{2}$ concentration to the historical increase in wheat yield in the U.S.

\section{Materials and methods}

\section{Controlled environment chamber}

Wheat was grown in an elongated chamber in which plants were exposed during daylight to a continuous gradient in $\mathrm{CO}_{2}$ concentration from near 200-350 $\mu \mathrm{mol}$ $\mathrm{mol}^{-1}$ (Mayeux et al. 1993). The $38 \mathrm{~m}$-long chamber is located in a ventilated glasshouse and consists of five parallel, $7.6 \mathrm{~m}$ lengths of a $0.76 \mathrm{~m}$-deep and $0.45 \mathrm{~m}$-wide soil container. Aerial growth of plants was enclosed in a transparent and tunnel-shaped polyethylene cover that was attached to the top edges of the soil container. Polyethylene covers of adjacent lengths of the chamber were connected by ducts to form a continuous 38-m system. The plastic-lined soil container was partitioned into $0.6 \mathrm{~m}$-long, water-tight compartments that were filled with fine sandy loam soil (Alfisol, Udic Paleustalfs; Huckabee et al. 1977). Soil pH was 7.1 and initial organic carbon content was $0.57 \%$.

Photosynthesis by plants within the chamber progressively reduced the $\mathrm{CO}_{2}$ concentration of chamber air from that in the glasshouse (about $350 \mu \mathrm{mol} \mathrm{mol}^{-1}$ ) to $200 \mu \mathrm{mol}$ $\mathrm{mol}^{-1}$ as air was moved by a blower from the air intake to the outlet of the system. The $\mathrm{CO}_{2}$ concentration gradient was maintained during daylight each day (daylight period $>8 \mathrm{~h}$ on $75 \%$ of days) by automatically varying the rate of air flow through the chamber in response to changes in incident light. The $\mathrm{CO}_{2}$ concentration was measured each minute with an infra-red gas analyser (Leybold-Heraeus, Hanau, Germany; Model BINOS 67) in air drawn from the chamber outlet and sequentially from five points spaced at $7.6 \mathrm{~m}$ - intervals along the chamber. Daytime $\mathrm{CO}_{2}$ concentration declined linearly with distance along the chamber from (mean \pm SE) $352 \pm 2 \mu \mathrm{mol} \mathrm{mol}^{-1}$ at the entrance to $204 \pm 1 \mu \mathrm{mol}$ $\mathrm{mol}^{-1}$ at the outlet. Blower speed was increased at night to vent $\mathrm{CO}_{2}$ generated by soil and plant respiration. The $\mathrm{CO}_{2}$ concentration at night increased from a mean $365 \mu \mathrm{mol} \mathrm{mol}^{-1}$ at the air inlet of the chamber to $400 \mu \mathrm{mol}$ $\mathrm{mol}^{-1}$ at the chamber outlet.

Photosynthetically active photon flux density (PPFD) was measured on the glasshouse roof with a quantum sensor (Li-Cor Inc., Nebraska, USA; Model LI-190SB) and above the polyethylene canopy with $1 \mathrm{~m}$ long line quantum sensors (LI-191SA). The PPFD incident on wheat in the chamber was calculated by multiplying quantum flux measured above the chamber by transmission of the polyethylene canopy (90\%). The daily integral of PPFD incident on plants in the $38 \mathrm{~m}$ chamber averaged $60 \%$ of that outside the glasshouse. Attenuation of PPFD was greatest in early morning and late evening. PPFD incident on plants within the chamber approached $80 \%$ of that outdoors during midday. Daily total PPFD varied by $5 \%$ among the five $7.6 \mathrm{~m}$ chamber lengths. The line quantum sensor used does not employ a full cosine correction, and so underestimates diffuse radiation and light at low solar angles. Attenuation of PPFD by the glasshouse and polyethylene canopy therefore likely was lower than calculated.

Dry bulb and dew point temperatures of air were regulated at the beginning of each $7.6 \mathrm{~m}$ length of the chamber with chilled-water cooling coils and resistance heating elements to track temporal changes in these temperatures within the glasshouse. Regulation each $7.6 \mathrm{~m}$ along the chamber suppressed the temperature and humidity gradients that develop in a semi-closed system. Dry bulb and dew point temperatures of air at the beginning and end of each length of chamber were monitored with $25 \mu \mathrm{m}$ diameter thermocouples and chilled-mirror hygrometers (General Eastern Instruments, Maine, USA; Model DEW-10), respectively. Vapor pressure deficit of air (VPD) at extremes of chamber lengths was calculated from these data.

The mean dry bulb temperature of conditioned air entering each $7.6 \mathrm{~m}$ length of chamber increased linearly from $18.5^{\circ} \mathrm{C}$ at the beginning of the experiment to $28.0^{\circ} \mathrm{C}$ at the end. The VPD of conditioned air increased linearly from 0.9 to $2.5 \mathrm{kPa}$ over the same period. Mean night-time temperature was $17^{\circ} \mathrm{C}$. Drybulb temperature increased a mean $3.8{ }^{\circ} \mathrm{C}$ and air VPD increased a mean $0.1 \mathrm{kPa}$ between points of regulation located each $7.6 \mathrm{~m}$ along the chamber. The repeated temperature and humidity gradients within each of the five chamber lengths did not appear to influence measured responses.

\section{Culture and harvest}

'Yaqui 54' and 'Seri M82', day-neutral cultivars of spring wheat, each were planted on 12 February 1991 in four 
$0.6 \mathrm{~m}$-long soil compartments in each of the five $7.6 \mathrm{~m}$ lengths of chamber (total of 20 compartments per cultivar). The spring wheat cultivar 'Glennson' was seeded into 0.6-m compartments in the middle and at extremes of chamber lengths well before Yaqui 54 and Seri M82 were planted. Glennson wheat served as a photosynthetic 'sink' for $\mathrm{CO}_{2}$ as air passed through the chamber, so that the desired $\mathrm{CO}_{2}$ gradient from near 350-200 $\mu \mathrm{mol} \mathrm{mol}^{-1}$ was established by 26 February, while seedlings of Seri M82 and Yaqui 54 were small.

Yaqui 54 is representative of 'traditional' tall cultivars, and was released about 40 years ago. Seri M82 is a semidwarf type more representative of modern spring wheats. Seedlings of the two cultivars were thinned on three occasions to a final density of 96 plants in each compartment on 17 April, the equivalent of 355 plants $\mathrm{m}^{-2}$. No fertilizer was provided. The nitrogen concentration of flag leaves from plants thinned on 17 April was high and uniform across the $\mathrm{CO}_{2}$ gradient, averaging $4.4 \%$ and $4.5 \%$ for Yaqui 54 and Seri M82, respectively, (Polley et al. 1993).

Soil water content was monitored weekly by neutron attenuation through the exterior plywood wall of each compartment with a surface moisture gauge (Troxler Electronics, North Carolina, USA; Model 3218). An empirically determined relationship between the volume of water lost per compartment and the decline in gauge reading from that at 'field capacity' was used to determine water deficit and to calculate water additions. Soil water in each compartment was restored to 'field capacity' weekly until 3 April. Additional water was withheld from half of the soil compartments with Yaqui 54 and Seri M82 in each $7.6 \mathrm{~m}$ chamber length for the final 50 days of the 100-day growing season (droughted treatment). Yaqui 54 was in the early boot stage when the different water treatments were imposed, but Seri M82 did not have flag leaves.

Numbers of vegetative tillers and spikes in each compartment were recorded on 22 May, after wheat matured. Spikes were harvested, oven-dried at $60^{\circ} \mathrm{C}$, and individually threshed by hand. Grains per spike were counted, and grain and chaff were weighed. Remaining aboveground tissues were separated into stems and leaves (sheaths and leaf blades), dried, and weighed. Area was measured before drying on a subsample of senescent and, when necessary, unfurled leaves from each compartment with a photoelectric leaf area meter. Leaf area per compartment was calculated by multiplying total leaf mass by specific leaf area of the subsample. Harvest index for each compartment was the ratio of grain mass to total above-ground biomass. Apparent water use efficiency (WUE) per compartment was calculated by dividing total above-ground biomass, including that removed when plants were thinned, by the volume of water lost during the experiment (evapotranspiration).

The mean daytime $\mathrm{CO}_{2}$ concentration to which plants in each $0.6 \mathrm{~m}$ soil compartment were exposed was estimated from a linear regression of $\mathrm{CO}_{2}$ concentration at the six locations routinely sampled on distance from the air intake of the chamber $\left(r^{2}=0.95\right)$. Linear regressions were used to describe relationships between plant parameters and daytime $\mathrm{CO}_{2}$ concentration. Higher order polynomial regressions and other non-linear relationships rarely provided a better fit to the data. For each plant parameter, separate linear regressions were fitted for each cultivar and water treatment. Regressions were compared with the $F$ statistic (Weisberg 1980).

\section{Results}

\section{Growth}

Leaf area index (LAI) of Yaqui 54 and Seri M82 at maturity increased linearly from about 1.0 and 1.4-2.0 and 3.0, respectively, with the $75 \%$ increase in $\mathrm{CO}_{2}$ concentration, regardless of watering regime (Fig. 1). Area was measured on senescent leaves, so LAI during grain fill likely was higher.

Above-ground biomass of well-watered Yaqui 54 and Seri M82 increased from about 230 and $310 \mathrm{~g} \mathrm{~m}^{-2}$ to an average of about $700 \mathrm{~g} \mathrm{~m}^{-2}$ over the $200-350 \mu \mathrm{mol} \mathrm{mol}^{-1}$ $\mathrm{CO}_{2}$ gradient, a gain of $136-193 \%$ (Fig. 2). Withholding water during the last half of the growing season significantly $(P<0.001)$ reduced above-ground biomass of each cultivar. The increase in biomass per unit increase in $\mathrm{CO}_{2}$ was halved by water stress in Seri M82, but did not differ significantly $(P>0.75)$ between watering treatments in Yaqui 54.

Plant height at harvest increased $(P<0.001)$ as $\mathrm{CO}_{2}$ rose, but was little affected by water treatment (not shown). Mean height of well-watered Seri M82 increased from $0.45-0.57 \mathrm{~m}$ and that of Yaqui 54 rose from 0.48 $0.66 \mathrm{~m}$ with the near $150 \mu \mathrm{mol} \mathrm{mol}{ }^{-1}$ increase in $\mathrm{CO}_{2}$ concentration.

\section{Grain yield}

Grain yield of well-watered plants of each cultivar more than tripled and yield of droughted Yaqui 54 increased about $150 \%$ with the near $150 \mu \mathrm{mol} \mathrm{mol}{ }^{-1}$ increase in $\mathrm{CO}_{2}$ concentration (Fig. 3). The linear relationship between grain yield and $\mathrm{CO}_{2}$ was only marginally significant $(P=0.07)$ in droughted Seri M82, however. Grain yield was significantly $(P<0.005)$ higher in Seri M82 than Yaqui 54 under well-watered conditions, but the increase in yield per unit increase in $\mathrm{CO}_{2}$ concentration 


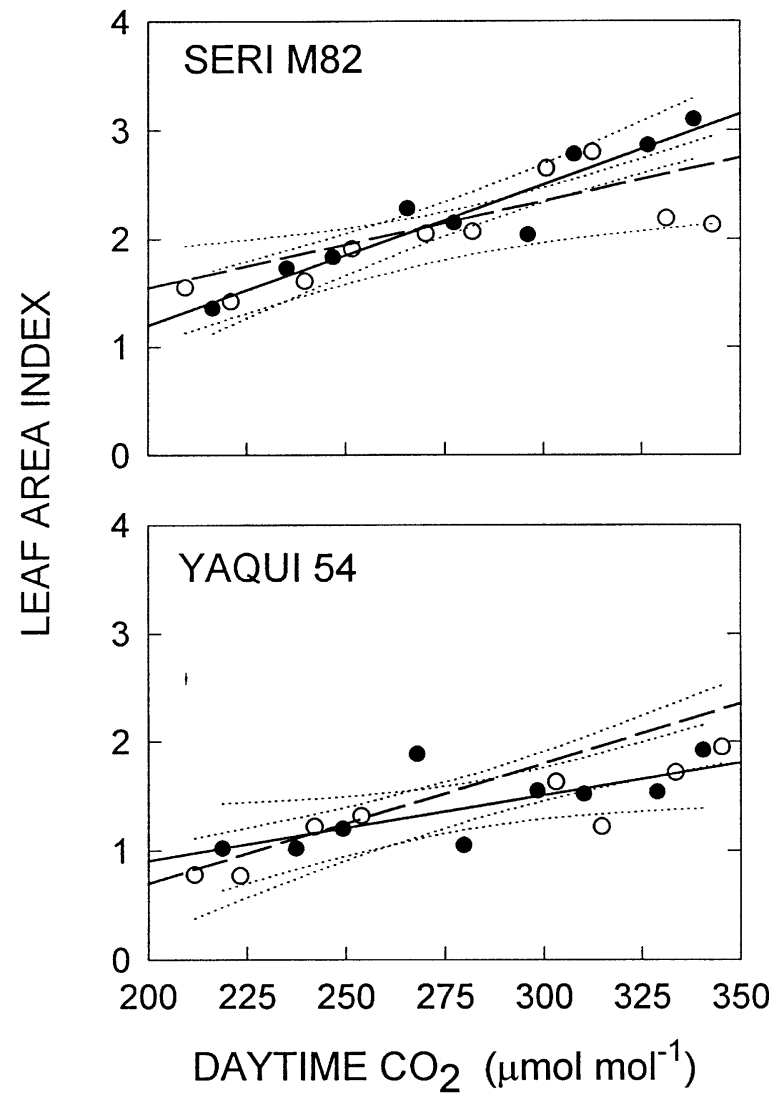

Fig. 1 Leaf area index (LAI) at maturity of well-watered (filled symbols) and droughted (open symbols) stands of two cultivars of spring wheat grown across a subambient $\mathrm{CO}_{2}$ gradient. Solid lines are linear regressions of LAI of wellwatered Seri M82 $\left(y=-1.4+0.013 x, r^{2}=0.90, P<0.001\right)$ and Yaqui $54\left(y=-0.29+0.006 x, r^{2}=0.50, P=0.033\right)$ on $\mathrm{CO}_{2}$. Dashed lines are linear regressions of LAI of droughted Seri M82 $\left(y=-0.05+0.008 x, r^{2}=0.60, P=0.009\right)$ and Yaqui $54\left(y=-1.5+0.011 x, r^{2}=0.82, P=0.008\right)$ on $\mathrm{CO}_{2}$. Dotted lines depict $95 \%$ confidence intervals for regression lines.

did not differ significantly $(P>0.75)$ between cultivars under either watering regime.

Grain yield increased proportionally more than did above-ground biomass in well-watered plants because of a $20-42 \%$ increase in harvest index over the full $\mathrm{CO}_{2}$ gradient (Fig. 4). Harvest index changed little above about $250 \mu \mathrm{mol} \mathrm{mol}{ }^{-1}$ in well-watered wheat, however, and was not significantly affected by $\mathrm{CO}_{2}$ when water was withheld during the latter half of the growing season. Tiller density (no. $\mathrm{m}^{-2}$ ) at harvest was not closely associated with $\mathrm{CO}_{2}$ concentration $\left(r^{2}=0.07-0.5\right)$ in either cultivar, and was not strongly depressed by withholding water (Fig. 5). Consequently, spike density did not change significantly with $\mathrm{CO}_{2}$ concentration $(P=0.13-0.58)$. The mean mass of individual grains was also not strongly or consistently influenced by $\mathrm{CO}_{2}$ (Fig. 6). Individual grain
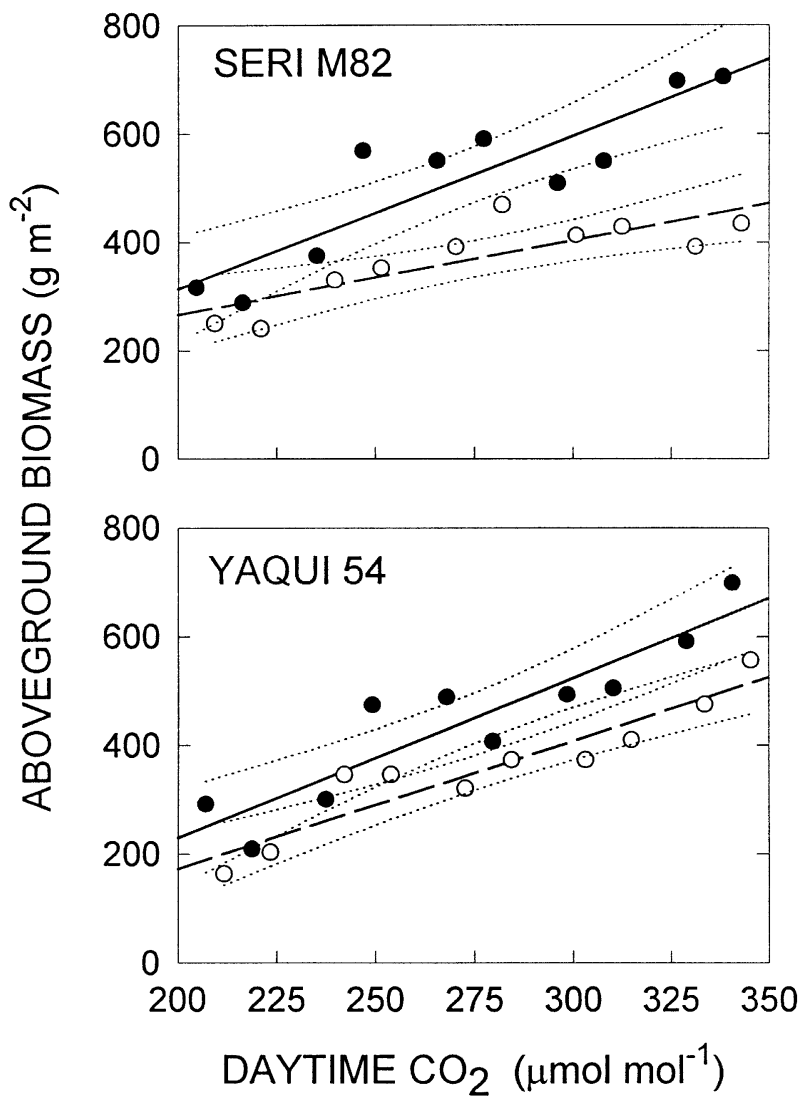

Fig. 2 Above-ground biomass at maturity of well-watered (filled symbols) and droughted (open symbols) plants of two cultivars of spring wheat grown across a subambient $\mathrm{CO}_{2}$ gradient. Solid lines are linear regressions of biomass of well-watered Seri M82 $\left(y=-254+2.83 x, r^{2}=0.80, P<0.001\right)$ and Yaqui 54 $\left(y=-359+2.94 x, r^{2}=0.84, P<0.001\right)$ on $\mathrm{CO}_{2}$. Dashed lines are linear regressions of biomass of droughted Seri M82 $\left(y=-12+1.39 x, r^{2}=0.68, P=0.003\right)$ and Yaqui 54 $\left(y=-298+2.35 x, r^{2}=0.88, P<0.001\right)$ on $\mathrm{CO}_{2}$. Dotted lines depict $95 \%$ confidence intervals for regression lines.

mass of well-watered plants was not affected by $\mathrm{CO}_{2}$ in Seri M82 (mean $=34.9 \pm 1.0 \mathrm{mg})$ and changed little in Yaqui 54 above about $250 \mu \mathrm{mol} \mathrm{mol} \mathrm{m}^{-1} \mathrm{CO}_{2}$. Mass per grain declined at higher $\mathrm{CO}_{2}$ concentrations $(P=0.02)$ in Seri M82 and did not change significantly with $\mathrm{CO}_{2}$ treatment $(P=0.57)$ in Yaqui 54 when water was withheld during grain fill.

By contrast, the number of grains per spike was highly sensitive to $\mathrm{CO}_{2}$ concentration. Grains per spike more than doubled in Yaqui 54 and droughted Seri M82 and more than tripled in well-watered Seri M82 from 200 to $350 \mu \mathrm{mol} \mathrm{mol}{ }^{-1} \mathrm{CO}_{2}$ (Fig. 7). Per unit rise in $\mathrm{CO}_{2}$ concentration, grains/spike increased by a similar amount in three of the four cultivar and watering treatment combinations. The increase was greatest in wellwatered Seri M82 $(P<0.05)$. 


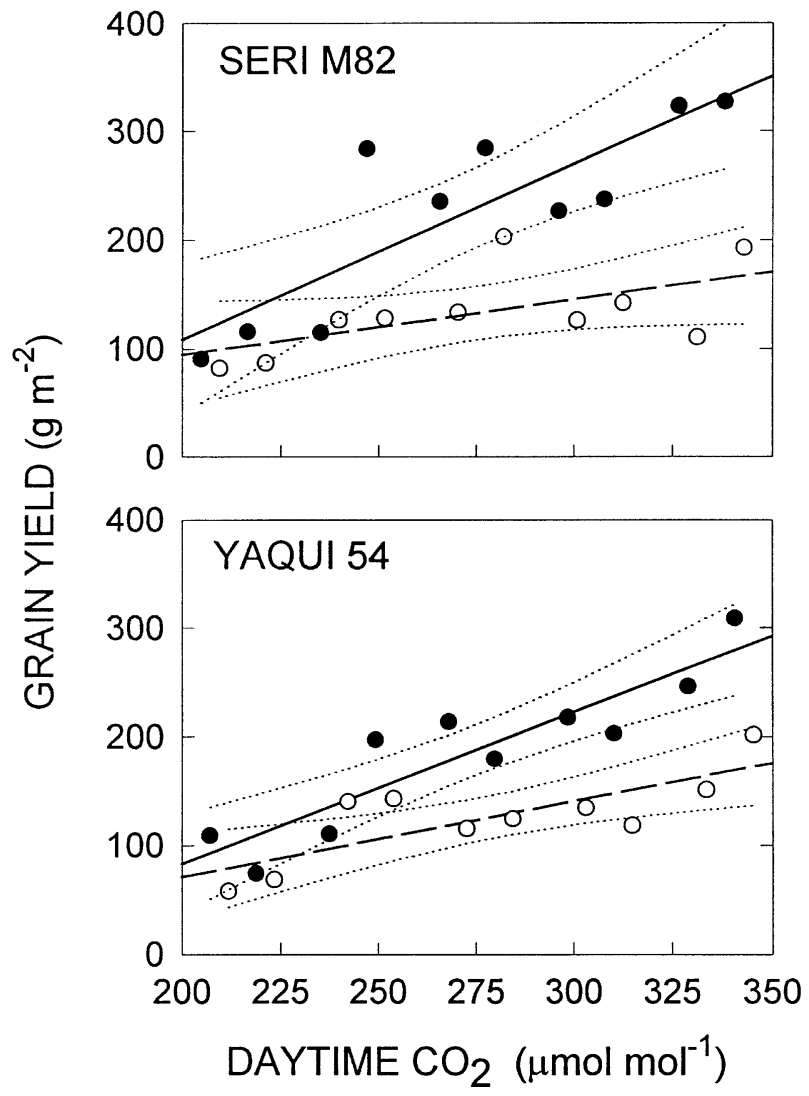

Fig. 3 Grain yield of well-watered (filled symbols) and droughted (open symbols) plants of two cultivars of spring wheat grown across a subambient $\mathrm{CO}_{2}$ gradient. Solid lines are linear regressions of grain yield of well-watered Seri M82 $(y=$ $\left.-214+1.61 x, r^{2}=0.71, P=0.002\right)$ and Yaqui $54(y=$ $\left.-196+1.40 x, r^{2}=0.82, P<0.001\right)$ on $\mathrm{CO}_{2}$. Dashed lines are linear regressions of grain yield of droughted Seri M82 $(y=$ $\left.-7.1+0.51 x, r^{2}=0.35, P=0.07\right)$ and Yaqui $54(y=-69+0.70 x$, $\left.r^{2}=0.61, P=0.007\right)$ on $\mathrm{CO}_{2}$. Dotted lines depict $95 \%$ confidence intervals for regression lines.

\section{Evapotranspiration and water use efficiency}

The large increases in biomass and leaf area as $\mathrm{CO}_{2}$ rose were accompanied by smaller increases in evapotranspiration (data not shown). The total volume of water added to maintain soil in compartments with Seri M82 near field capacity ranged from $63.6 \mathrm{~L}$ at the lowest $\mathrm{CO}_{2}$ level to $87.2 \mathrm{~L}$ at the highest concentration. Cumulative water additions to well-watered Yaqui 54 compartments increased $22 \%$, from 65.4 to $80.0 \mathrm{~L}$, at higher $\mathrm{CO}_{2}$ concentration. Cumulative water additions to droughted Seri M82 did not differ with $\mathrm{CO}_{2}$ treatment (mean $=51 \mathrm{~L}$ per compartment). The volume of water added to droughted Yaqui 54 increased linearly from 43.1-54.5 L with increasing $\mathrm{CO}_{2}$.

$\mathrm{CO}_{2}$-caused increases in WUE of above-ground biomass production of both cultivars were significant,

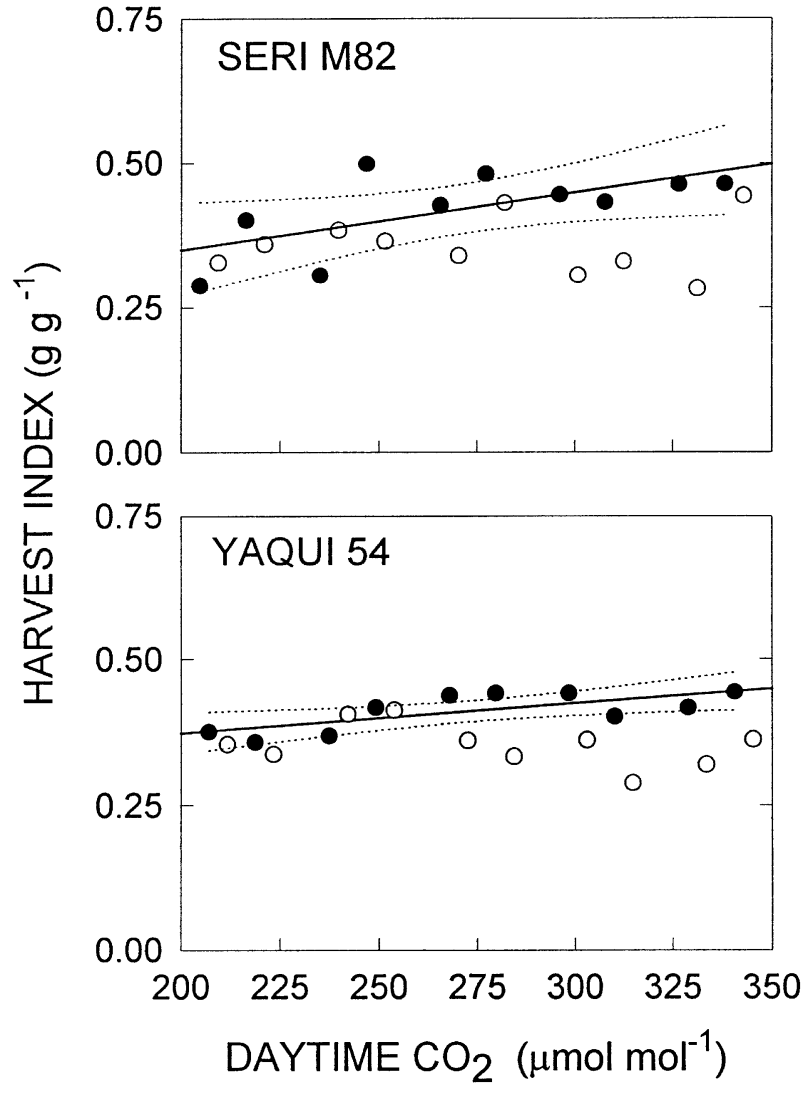

Fig. 4 Harvest index of well-watered (filled symbols) and droughted (open symbols) plants of two cultivars of spring wheat grown across a subambient $\mathrm{CO}_{2}$ gradient. Solid lines are linear regressions of the index for well-watered Seri M82 $(y=$ $\left.0.153+0.001 x, r^{2}=0.41, P=0.05\right)$ and Yaqui $54(y=$ $\left.0.27+0.0005 x, r^{2}=0.51, P=0.02\right)$ on $\mathrm{CO}_{2}$. Dotted lines depict $95 \%$ confidence intervals for regression lines. Harvest index of droughted plants was not related to $\mathrm{CO}_{2}$.

although only marginally so in droughted Seri M82 $(P=$ 0.10 ), and similar in magnitude (Fig. 8). WUE increased from less than 2 to about $3 \mathrm{~g} \mathrm{~L}^{-1}$ with increasing $\mathrm{CO}_{2}$. WUE tended to be higher in droughted than well-watered plants because above-ground biomass declined less than did evapotranspiration when water was withheld.

The level of water stress that developed in droughted treatments over the 50 days of deprivation was not severe until near the end of the experiment, but evapotranspiration in droughted compartments declined to about 50\% of that in continuously watered compartments. Evapotranspiration over the 44 days prior to 15 May averaged $24 \mathrm{~L}$ and $47 \mathrm{~L}$ in droughted and continuously watered compartments, respectively. Average volumetric water content on 15 May, 7 days before harvest, was $16.8 \%$ in the droughted soil compartments and $22.5 \%$ (the approximate field capacity) in the well-watered compartments. 


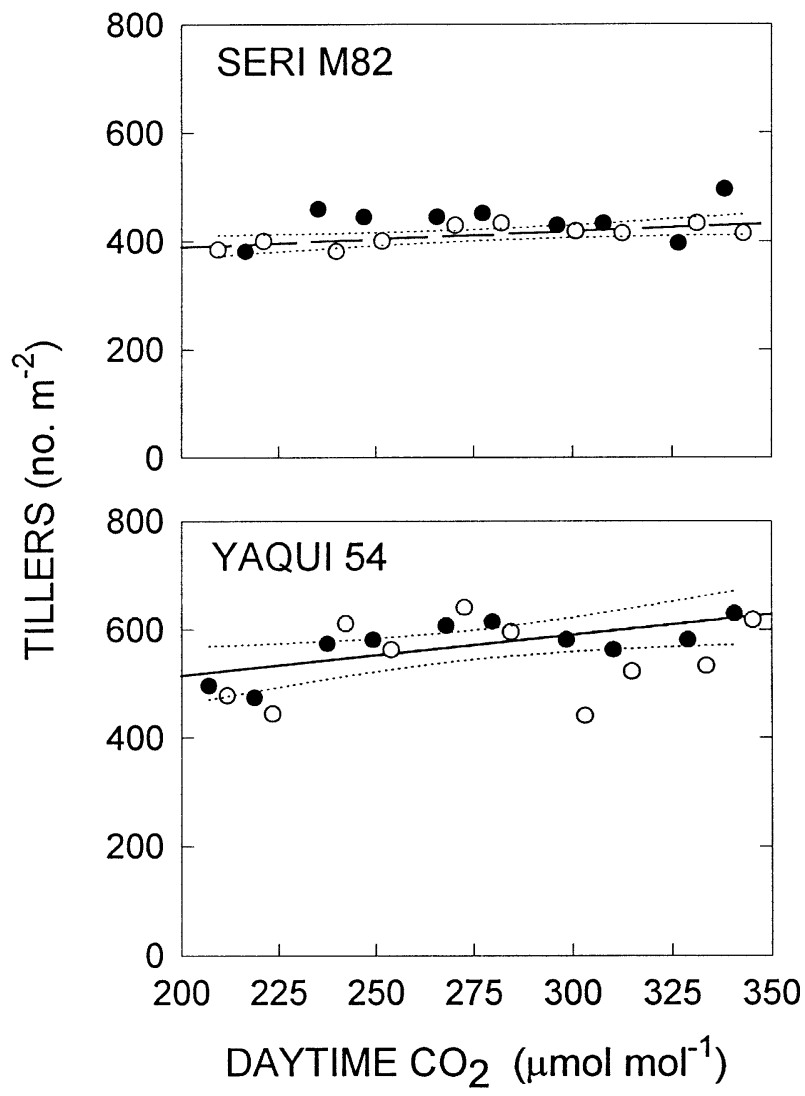

Fig. 5 Tiller density of well-watered (filled symbols) and droughted (open symbols) plants of two cultivars of spring wheat grown across a subambient $\mathrm{CO}_{2}$ gradient. The solid line is a linear regression of tillers $\mathrm{m}^{-1}$ of well-watered Yaqui 54 $\left(y=361+0.765 x, r^{2}=0.50, P=0.02\right)$ on $\mathrm{CO}_{2}$. The dashed line is a linear regression of tillers $\mathrm{m}^{-1}$ of droughted Seri M82 $\left(y=331+0.291 x, r^{2}=0.50, P=0.02\right)$ on $\mathrm{CO}_{2}$. Dotted lines depict $95 \%$ confidence intervals for regression lines. Tiller density in other treatments was not related to $\mathrm{CO}_{2}$.

\section{Discussion}

\section{Grain yield}

A $27 \%$ increase in $\mathrm{CO}_{2}$ from the pre-industrial concentration $\left(275 \mu \mathrm{mol} \mathrm{mol}^{-1}\right)$ to near the current level $(350 \mu \mathrm{mol}$ $\mathrm{mol}^{-1}$ ) increased grain yields of Yaqui 54 and Seri M82 spring wheats more than $50 \%$ under well-watered conditions (Fig. 3). Grain yields of the two cultivars more than tripled when well-watered and increased $80 \%$ to $150 \%$ when droughted during the latter half of the growing season as $\mathrm{CO}_{2}$ rose nearly $75 \%$ from slightly above 200 to about $350 \mu \mathrm{mol} \mathrm{mol}{ }^{-1}$. These proportional increases generally exceed the $80 \%$ increase in yield of spring wheat grown in pots over a comparable $\mathrm{CO}_{2}$ range, $150-300 \mu \mathrm{mol} \mathrm{mol}^{-1}$ (Gifford 1977). They also exceed proportional increases in yield of usually $60 \%$ or less when wheat or other $C_{3}$ crops are exposed to elevated $\mathrm{CO}_{2}$ concentrations (Kimball 1983;
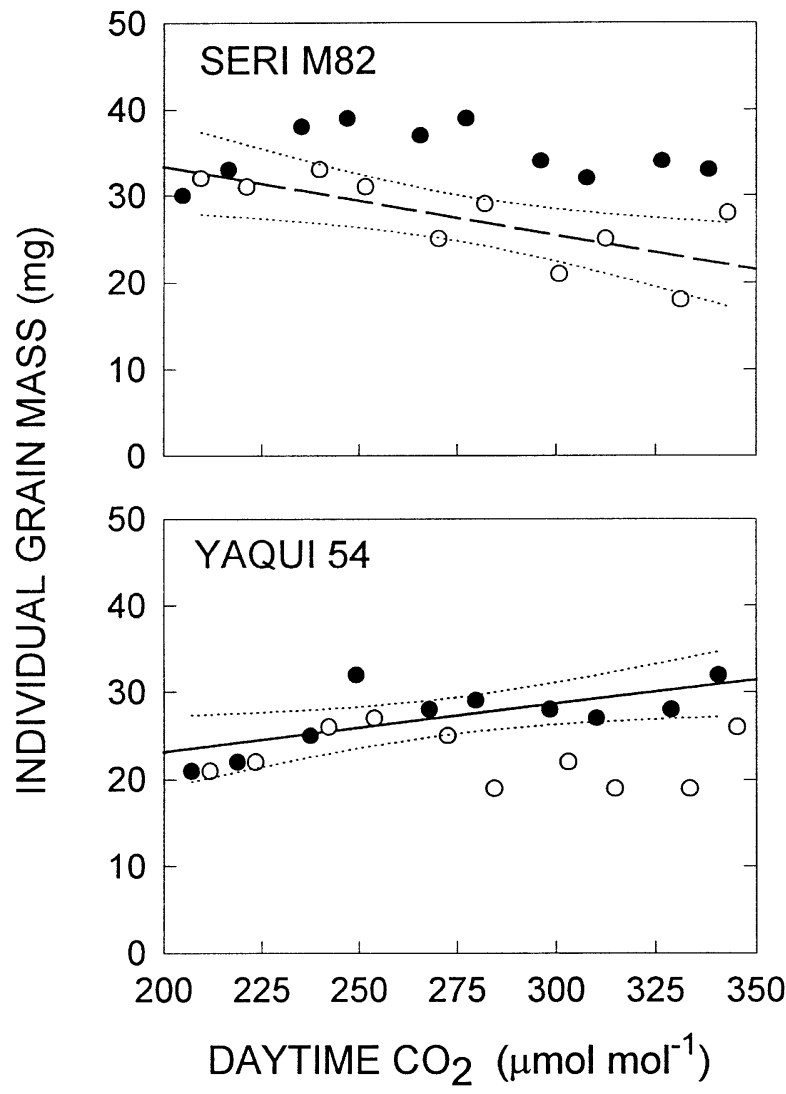

Fig. 6 Mass of individual grains of well-watered (filled symbols) and droughted (open symbols) plants of two cultivars of spring wheat grown across a subambient $\mathrm{CO}_{2}$ gradient. The solid line is a linear regression of grain mass of well-watered Yaqui 54 $\left(y=12.1+0.06 x, r^{2}=0.48, P=0.03\right)$ on $\mathrm{CO}_{2}$. The dashed line is a linear regression of grain mass of droughted Seri M82 $\left(y=49.2-0.08 x, r^{2}=0.53, P=0.02\right)$ on $\mathrm{CO}_{2}$. Dotted lines depict $95 \%$ confidence intervals for regression lines. Grain mass in other treatments was not related to $\mathrm{CO}_{2}$.

Cure \& Acock 1986; Baker et al. 1990; Allen et al. 1991; Lawlor \& Mitchell 1991; Kimball et al. 1995). Per unit increase in $\mathrm{CO}_{2}$, however, the increases in yield that we observed are similar to those of spring wheat grown from

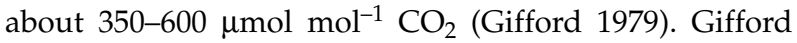
(1979) observed that grain yield of spring wheat rose 0.5 and $1.3 \mathrm{~g} \mathrm{~m}^{-2}$ for each annual increment in the current rise in atmospheric $\mathrm{CO}_{2}$ concentration, $1.2 \mu \mathrm{mol} \mathrm{mol}^{-1}$, under water-stressed and well-watered conditions, respectively. Grain yield of Seri M82 and Yaqui 54 increased about $0.5 \mathrm{~g}$ $\mathrm{m}^{-2}$ per $\mu \mathrm{mol} \mathrm{mol}{ }^{-1}$ increase in subambient $\mathrm{CO}_{2}$ under late-season drought, and 1.6 and $1.4 \mathrm{~g} \mathrm{~m}^{-2}$ per $\mu \mathrm{mol} \mathrm{mol}^{-1}$ rise in $\mathrm{CO}_{2}$ under well-watered conditions, respectively.

\section{Yield components}

Increases in grain yield of Seri M82 and Yaqui 54 wheat resulted almost entirely from greater numbers of grains 


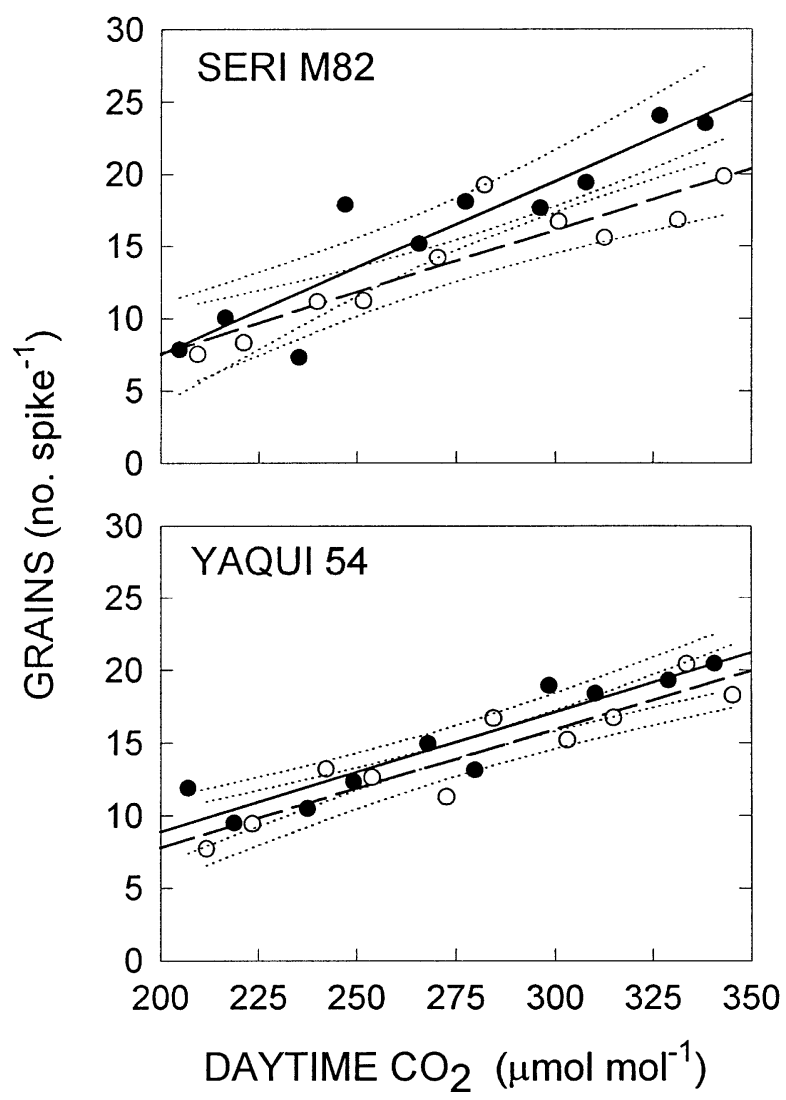

Fig. 7 Number of grains per spike of well-watered (filled symbols) and droughted (open symbols) plants of two cultivars of spring wheat grown across a subambient $\mathrm{CO}_{2}$ gradient. Solid lines are linear regressions of grains spike $\mathrm{e}^{-1}$ of well-watered Seri M82 $\left(y=-16.5+0.120 x, r^{2}=0.85, P<0.001\right)$ and Yaqui 54 $\left(y=-7.5+0.082 x, r^{2}=0.87, P<0.001\right)$ on $\mathrm{CO}_{2}$. Dashed lines are linear regressions of grains spike ${ }^{-1}$ of droughted Seri M82 $\left(y=-9.6+0.086 x, r^{2}=0.82, P<0.001\right)$ and Yaqui 54 $\left(y=-8.4+0.081 x, r^{2}=0.85, P<0.001\right)$ on $\mathrm{CO}_{2}$. Dotted lines depict $95 \%$ confidence intervals for regression lines.

per spike in both well-watered and droughted plants (Fig. 7). Mass per grain, tillering, and numbers of fertile spikes per plant were not consistently affected by $\mathrm{CO}_{2}$. In previous experiments with wheat, number of grains per spike increased with (Krenzer \& Moss 1975; Gifford 1977, 1979; Chaudhuri et al. 1990) or was not affected by $\mathrm{CO}_{2}$ (Sionit et al. 1980), but number of grains per plant or per unit area invariably increased. Irrespective of water or other stresses, tillering and the number of spikes per plant or per unit area are yield components that often respond positively to elevated $\mathrm{CO}_{2}$ (Gifford 1979; Sionit et al. 1980; Sionit et al. 1981 a, b; Chaudhuri et al. 1990). No significant increase in tillering occurred in this experiment, perhaps because of the high plant density (355 plants $\mathrm{m}^{-2}$ ) relative to other reports, although density in our experiment was equivalent to that recommended for the field in our geographical area. The progressive

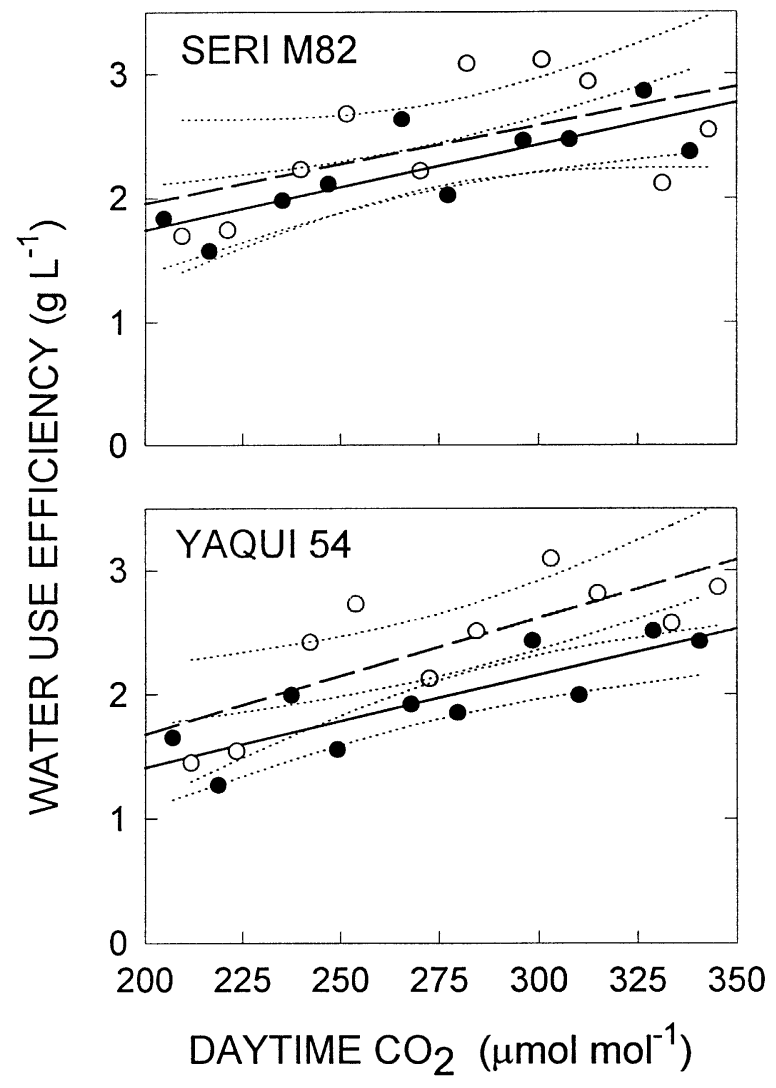

Fig. 8 Water use efficiency of above-ground biomass production (WUE) of well-watered (filled symbols) and droughted (open symbols) plants of two cultivars of spring wheat grown across a subambient $\mathrm{CO}_{2}$ gradient. Solid lines are linear regressions of WUE of well-watered Seri M82 $\left(y=0.37+0.007 x, r^{2}=0.64\right.$, $P=0.006)$ and Yaqui $54\left(y=-0.08+0.007 x, r^{2}=0.71, P=0.002\right)$ on $\mathrm{CO}_{2}$. Dashed lines are linear regressions of WUE of droughted Seri M82 $\left(y=0.70+0.006 x, r^{2}=0.31, P=0.10\right)$ and Yaqui 54 $\left(y=-0.19+0.009 x, r^{2}=0.61, P=0.008\right)$ on $\mathrm{CO}_{2}$. Dotted lines depict $95 \%$ confidence intervals for regression lines.

thinning of plants during this experiment may also have lessened $\mathrm{CO}_{2}$ effects on tillering. Wheat was at or beyond the boot stage and, thus, the period when tillering would be responsive to $\mathrm{CO}_{2}$ when plants were thinned to final density. In a previous experiment conducted in the same chamber, above-ground biomass of oats (Avena sativa L.) increased nearly $300 \%$ from about $150-330 \mu \mathrm{mol} \mathrm{mol}{ }^{-1}$ $\mathrm{CO}_{2}$ when grown at a density of 15 plants $\mathrm{m}^{-2}$ (Polley et al. 1992). The increase in oat biomass reflected a $65 \%$ increase in tillers per plant and $76 \%$ increase in biomass per tiller.

Mass per grain of wheat increased in some (Krenzer \& Moss 1975; Sionit et al. 1980; Sionit et al. 1981b; Chaudhuri et al. 1990), but not all (Combe 1981; Gifford 1979) studies at the current and elevated $\mathrm{CO}_{2}$ levels. Atmospheric $\mathrm{CO}_{2}$ had little or no effect on the mass of individual grains in well-watered plants in this study 

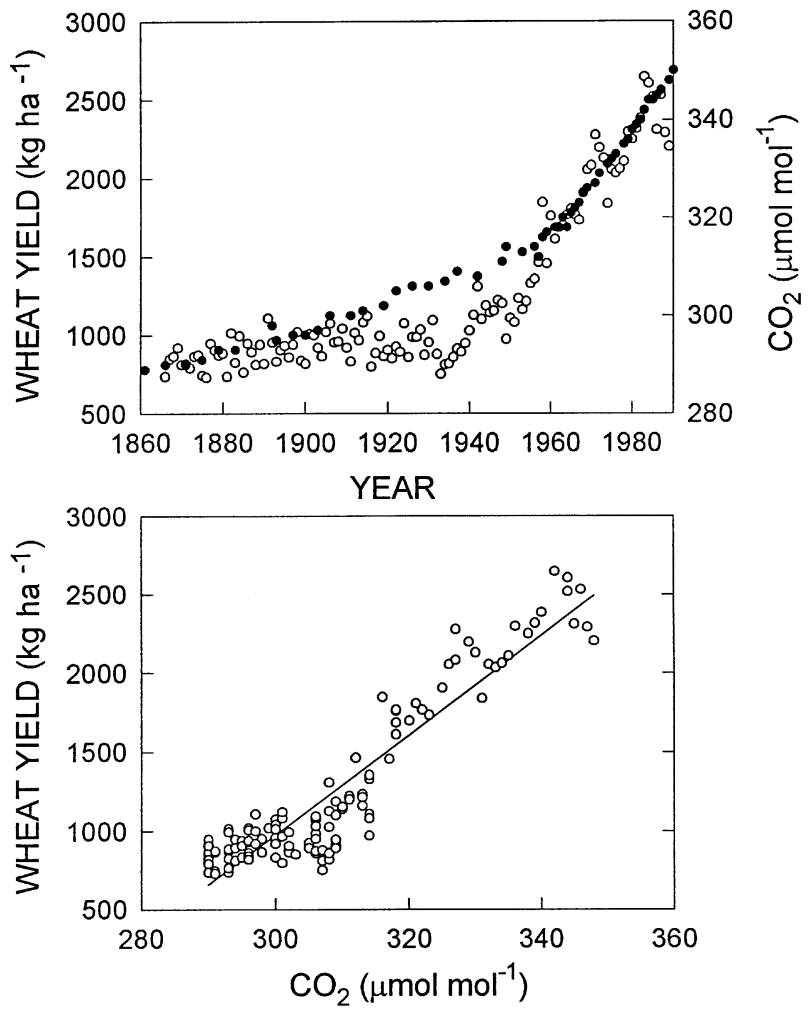

Fig. 9 Average United States wheat yields from 1866 to 1989 (open symbols) and atmospheric $\mathrm{CO}_{2}$ concentration (filled symbols) over the same time period (upper), and the linear regression of national annual average wheat yields against $\mathrm{CO}_{2}$ concentration (lower; $y=31.6 x-8501, r^{2}=0.87, P=0.0001$ ). Yields include all types of wheat and were compiled from the United States Department of Agriculture's Agricultural Statistics (1936 through 1990). Atmospheric $\mathrm{CO}_{2}$ data are from Friedli et al. (1986).

(Fig. 6). Withholding water during grain-filling, eliminated any positive effect of $\mathrm{CO}_{2}$ on mass per grain in Yaqui 54 and caused grain mass to decrease as $\mathrm{CO}_{2}$ rose in the later-maturing Seri M82. This decrease in mass per grain in Seri M82 resulted in lower grain yield (Fig. 3) and harvest index (Fig. 4) under drought, particularly at $\mathrm{CO}_{2}$ concentrations approaching the current level.

The drought treatment had a more detrimental effect on yield of Seri M82 than Yaqui 54 and at the current than lower $\mathrm{CO}_{2}$ concentrations. These trends partly reflected the timing of water deprivation and differences in cumulative water supplied. Because water was withheld from the early boot stage to maturity, the severity of stress increased progressively after the midpoint of the growing season. Stress developed too late to significantly influence tillering and spike density. Water deficits developed after floral initiation and spikelet number was established, so the number of grains per spike was not greatly affected by drought. Drought did influence mass per grain, however, especially in the later-maturing cultivar Seri M82.

Differences in cumulative irrigation also contributed to the greater sensivity of yield to drought treatments at the current than lower $\mathrm{CO}_{2}$ concentrations, especially in Seri M82. About $25 \mathrm{~L}$ less water was added to droughted than well-watered compartments with Yaqui 54 over the experiment, regardless of $\mathrm{CO}_{2}$ treatment. By contrast, the difference in water added to well-watered compared to droughted compartments with Seri M82 increased from about $13-36 \mathrm{~L}$ as $\mathrm{CO}_{2}$ rose.

\section{Factors contributing to yield responses to $\mathrm{CO}_{2}$}

The highly positive responses of above-ground biomass and grain yield to $\mathrm{CO}_{2}$ in wheat resulted from a variety of physiological changes (Polley et al. 1993). Daytime net assimilation of Seri M82 and Yaqui 54 canopies more than doubled as $\mathrm{CO}_{2}$ rose, while the ratio of night-time respiration to daytime net assimilation declined linearly with $\mathrm{CO}_{2}$ concentration (Polley et al. 1993). Consequently, daily (24-h) net $\mathrm{CO}_{2}$ accumulation per unit soil surface area increased dramatically from low to high $\mathrm{CO}_{2}$ concentration, from about 180 to $450 \mu \mathrm{mol} \mathrm{CO} \mathrm{Cm}^{-2} \mathrm{~d}^{-1}$ during March and from 120 to $500 \mu \mathrm{mol} \mathrm{m}{ }^{-2} \mathrm{~d}^{-1}$ during the first 2 weeks of April. The light compensation point of wheat canopies (the daily total of PPFD required for positive carbon assimilation) declined as $\mathrm{CO}_{2}$ rose, suggesting that light use efficiency, like WUE (Fig. 8), increased with $\mathrm{CO}_{2}$ concentration. The large increases in above-ground biomass and grain yield thus reflected positive contributions of carbon assimilation and retention that were proportionally greater than the increase in $\mathrm{CO}_{2}$ concentration over a broad subambient range.

\section{Historical wheat yields and $\mathrm{CO}_{2}$}

Annual world wheat production during recent decades rose $86 \%$ but the total area sown to wheat increased only $25.4 \%$, suggesting that yields increased 'due to improved varieties and cultural practices' (Arnon 1972). Atmospheric $\mathrm{CO}_{2}$ concentration also rose rapidly during recent decades. Growth and yield of wheat are highly sensitive to subambient $\mathrm{CO}_{2}$ concentrations, implying that rising atmospheric $\mathrm{CO}_{2}$ has been partly responsible for the upward trend in yield of this crop (Gifford 1979).

Goudriaan \& Unsworth (1990) found a near-perfect relationship between world average cereal grain yield per unit area and $\mathrm{CO}_{2}$ measurements at Mauna Loa, Hawaii from 1959 to 1986 . They reasoned that rising $\mathrm{CO}_{2}$ contributed about $1 / 14$, or $7 \%$, of the yield increase because the relative increase in grain yield has been seven times the relative increase in $\mathrm{CO}_{2}$ concentration and the biotic growth (or yield enhancement) factor observed 
in experiments (ratio of proportional yield increase to proportional $\mathrm{CO}_{2}$ increase) rarely exceeds 0.5 . Yield enhancement factors calculated for grain from our experiment range from 1.0 to 1.4 for the two cultivars when droughted, and are $\approx 1.7$ and 1.8 for well-watered Seri M82 and Yaqui 54, respectively. Using these values, corresponding proportions of the increase in world average grain yield attributable to rising $\mathrm{CO}_{2}$ concentration for the period addressed by Goudriaan \& Unsworth (1990) are $14-20 \%$ under drought and approach $25 \%$ under well-watered conditions.

Average wheat yields in the United States (U.S. Department of Agriculture 1936-90) and atmospheric $\mathrm{CO}_{2}$ concentration are correlated over the 123-year period for which yield data are available $\left(r^{2}=0.87\right.$; Fig. 9), but the correlation is especially strong during the last few decades when the rate of increase in $\mathrm{CO}_{2}$ concentration was greatest. National average yields increased about $1250 \mathrm{~kg}$ $\mathrm{ha}^{-1}$ (from 1350 to $2600 \mathrm{~kg} \mathrm{ha}^{-1}$ ) between 1955 and 1990, while atmospheric $\mathrm{CO}_{2}$ concentration rose $40 \mu \mathrm{mol} \mathrm{mol}^{-1}$ (from 312 to $352 \mu \mathrm{mol} \mathrm{mol}{ }^{-1}$ ). Regressions of grain yields on $\mathrm{CO}_{2}$ concentration for the two spring wheat cultivars in this experiment (Fig. 3) indicate a mean increase of 242 and $602 \mathrm{~kg} \mathrm{ha}^{-1}$ in grain yield when droughted and well-watered, repectively, with the $40 \mu \mathrm{mol} \mathrm{mol}^{-1}$ increase in $\mathrm{CO}_{2}$ from 312 to $352 \mu \mathrm{mol} \mathrm{mol}^{-1}$ that occurred between 1955 and 1990. These suggest that rising $\mathrm{CO}_{2}$ concentration has accounted for $19-48 \%$ of the observed increase in average yields of wheat in the U.S. over the last few decades, or fully a third, 33\%, if these experimentally determined increases in grain yields of droughted and well-watered wheat are averaged.

The observed response of wheat to $\mathrm{CO}_{2}$ and, consequently, both of our estimates of the contribution of $\mathrm{CO}_{2}$ to historical increases in wheat yield should be regarded as near maximal. Plants were grown in fertile soil at relatively high temperatures and in narrow stands. Attenuation of lateral light by neighbouring plants thus was minimal compared to the shading that occurs in field plantings. Under well-watered conditions, plants experienced no water stress, and wheat grown near today's $\mathrm{CO}_{2}$ level used $22-37 \%$ more water over the experiment than plants grown at the lowest concentration. The data do, however, demonstrate the extreme sensitivity of wheat yield to past increases in $\mathrm{CO}_{2}$ concentration.

Each of the methods used to calculate the contribution of rising $\mathrm{CO}_{2}$ to the recent increase in wheat yield produced lower-range estimates of about $15-20 \%$. These estimates are two- to three-times those calculated without the benefit of experimental data on the response of wheat yield to subambient $\mathrm{CO}_{2}$ concentrations (Goudriaan \& Unsworth 1990; Amthor 1995).

Much of the recent increase in wheat yield undoubtedly reflects development of varieties better adapted to specific wheat-growing areas and with greater disease-resistance and physiological yield potential (Deckerd et al. 1985; Perry \& D'Antuono 1989). These examples of progress in breeding, like cultural innovations such as effective pesticides and widespread use of nitrogen fertilizers, however, were introduced or widely employed in some areas, like the U.S., well after wheat yields began to climb rapidly during the 1950 s.

\section{Acknowledgements}

Anne Gibson, Katherine Jones and Mark Dumesnil assisted in data collection, analysis, and presentation. Milton McDaniel advised us on the selection of cultivars, and Charles Erickson, John Heaton, and Cal Qualset provided seed. Jeffrey Baker, Al Frank, Thomas Gerik, Bruce Kimball, and Jim Kiniry provided helpful comments on the manuscript. Research was supported in part by the U.S. Department of Agriculture, Cooperative State Research Service under agreement no. 91-37100-6633 and National Research Initiative Competitive Grants Program/ USDA under agreement no. 94-37100-0692.

\section{References}

Allen LH Jr, Bisbal EC, Boote KJ, Jones PH (1991) Soybean dry matter allocation under subambient and superambient levels of carbon dioxide. Agronomy Journal, 83, 875-883.

Amthor JS (1995) Terrestrial higher-plant response to increasing atmospheric $\left[\mathrm{CO}_{2}\right]$ in relation to the global carbon cycle. Global Change Biology, 1, 243-274.

Arnon I (1972) Crop Production in Dry Regions, Vol. II: Systematic Treatment of the Principal Crops. Barnes \& Noble, New York.

Baker JT, Allen LH Jr, Boote KJ (1990) Growth and yield response of rice to carbon dioxide concentration. Journal of Agricultural Science, 11, 313-320.

Bacastow RB, Keeling CD, Whorf TP (1985) Seasonal amplitude increase in atmospheric $\mathrm{CO}_{2}$ concentration at Mauna Loa, Hawaii, 1959-1982. Journal of Geophysical Research, 90, 10529-10540.

Chaudhuri UN, Kirkham MB, Kanemasu ET (1990) Carbon dioxide and water level effects on yield and water use of winter wheat. Agronomy Journal, 82, 637-641.

Combe L (1981) Effect of carbon dioxide and culture under artificial climate on the growth and yield of a winter wheat. Agronomie, 1, 177-186.

Cure JD, Acock B (1986) Crop responses to carbon dioxide doubling: A literature survey. Agriculture and Forest Meteorology, 38, 127-145.

Deckerd EL, Busch RH, Kofoid KD (1985) Physiological aspects of spring wheat improvement. In: Exploitation of Physiological and Genetic Variability to Enhance Crop Productivity (eds Harper JE, Schrader LE, Howell RW), pp. 46-54. American Society of Plant Physiologists, Rockville, MD.

Delmas RJ, Ascencio J-M, Legrand M (1980) Polar ice evidence that atmospheric $\mathrm{CO}_{2} 20000$ year BP was $50 \%$ of present. Nature, 284, 155-157.

Dippery JK, Tissue DT, Thomas RB, Strain BR (1995) Effects of 
low and elevated $\mathrm{CO}_{2}$ on $\mathrm{C}_{3}$ and $\mathrm{C}_{4}$ annuals I. Growth and biomass allocation. Oecologia, 101, 13-20.

Ehleringer JR, Sage RF, Flanagan LB, Pearcy RW (1991) Climate change and the evolution of $\mathrm{C}_{4}$ photosynthesis. Trends in Ecology and Evolution, 6, 95-99.

Friedli H, Lotscher H, Oeschger H, Siegenthaler U, Stauffer B (1986) Ice core record of the ${ }^{13} \mathrm{C} /{ }^{12} \mathrm{C}$ ratio of atmospheric $\mathrm{CO}_{2}$ in the past two centuries. Nature, 324, 237-238.

Gifford RM (1977) Growth pattern, carbon dioxide exchange and dry matter distribution in wheat growing under differing photosynthetic environments. Australian Journal of Plant Physiology, 4, 99-110.

Gifford RM (1979) Growth and yield of $\mathrm{CO}_{2}$-enriched wheat under water-limited conditions. Australian Journal of Plant Physiology, 6, 367-378.

Goudriaan J, de Ruiter HE (1983) Plant growth in response to $\mathrm{CO}_{2}$ enrichment, at two levels of nitrogen and phosphorous supply. 1. Dry matter, leaf area and development. Netherland Journal of Agricultural Science, 31, 157-169.

Goudriaan J, Unsworth MH (1990) Implications of increasing carbon dioxide and climate change for agricultural productivity and water resources. In: Impact of Carbon Dioxide, Trace Gases, and Climate Change on Global Agriculture (eds Kimball BA, Rosenberg NR, Allen Jr LH), pp. 111-130. Special Publication Number 53. American Society of Agronomy, Madison.

Huckabee JW Jr, Thompson DR, Wyrick JC, Paulat EG (1977) Soil Survey Bell County Texas. USDA Soil Conservation Service, Washington, D.C., $165 \mathrm{pp}$.

Johnson HB, Polley HW, Mayeux HS (1993) Increasing $\mathrm{CO}_{2}$ and plant-plant interactions: effects on natural vegetation. Vegetatio, 104/105, 157-170.

Keeling CD, Whorf TP (1994) Atmospheric $\mathrm{CO}_{2}$ records from sites in the SIO air sampling network. In: Trends '93: A Compendium of Data on Global Change (eds Boden TA, Kaiser DP, Sepanski RJ, Stoss FW), pp. 16-26. Carbon Dioxide Information Analysis Center, Oak Ridge National Laboratory, Oak Ridge, TN

Kimball BA (1983) Carbon dioxide and agricultural yield: An assemblage and analysis of 430 prior observations. Agronomy Journal, 75, 779-788.

Kimball BA, Pinter PJ Jr, Garcia RL et al. (1995) Productivity and water use of wheat under free-air $\mathrm{CO}_{2}$ enrichment. Global Change Biology, 1, 429-442.

Krenzer EG Jr, Moss DN (1975) Carbon dioxide enrichment effects upon yield and yield components in wheat. Crop Science, 15, 71-74.
Lawlor DW, Mitchell RAC (1991) The effects of increasing $\mathrm{CO}_{2}$ on crop photosynthesis and productivity: a review of field studies. Plant, Cell, and Environment, 14, 807-818.

Loomis RS (1983) Productivity of agricultural systems. In: Physiological Plant Ecology IV (eds Lange OL, Nobel PS, Osmond CB, Ziegler H), pp. 151-172. Springer-Verlag, Berlin.

Mayeux HS, Johnson HB, Polley HW, Dumesnil MJ, Spanel GA (1993) A controlled environment chamber for growing plants across a subambient $\mathrm{CO}_{2}$ gradient. Functional Ecology, 7, 125-133.

Neftel A, Oeschger H, Staffelbach T, Stauffer B (1988) $\mathrm{CO}_{2}$ record in the Byrd ice core 50000 year BP. Nature, 331, 609-611.

Perry MW, D'Antuono MF (1989) Yield improvement and associated characteristics of some Australian spring wheat cultivars introduced between 1860 and 1982 Australian Journal of Agricultural Research, 40, 457-472

Polley HW, Johnson HB, Mayeux HS (1992) Growth and gas exchange of oats (Avena sativa) and wild mustard (Brassica kaber) at subambient $\mathrm{CO}_{2}$ concentrations. International Journal of Plant Sciences, 153, 453-461.

Polley HW, Johnson HB, Mayeux HS, Malone SR (1993) Physiology and growth of wheat across a subambient carbon dioxide gradient. Annals of Botany, 71, 347-356.

Sage RF (1995) Was low atmospheric $\mathrm{CO}_{2}$ during the Pleistocene a limiting factor for the origin of agriculture? Global Change Biology, 1, 93-106.

Sionit N, Hellmers H, Strain BR (1980) Growth and yield of wheat under $\mathrm{CO}_{2}$ enrichment and water stress. Crop Science, 20, 687-690.

Sionit N, Mortensen DA, Strain BR, Hellmers H (1981a) Growth response of wheat to $\mathrm{CO}_{2}$ enrichment and different levels of mineral nutrition. Agronomy Journal, 73, 1023-1027.

Sionit N, Strain BR, Hellmers H (1981b) Effects of different concentrations of atmospheric $\mathrm{CO}_{2}$ on growth and yield components of wheat. Journal of Agricultural Science, 79, 335-339.

Strain BR (1992) Atmospheric carbon dioxide: a plant fertilizer? New Biologist, 4, 87-89.

Trabalka JR, Edmonds JA, Reilly JM, Gardner RH, Voorhees LD (1985) Human alterations of the global carbon cycle and the projected future. In: Atmospheric Carbon Dioxide and the Global Carbon Cycle (ed. Trabalka JR), pp. 247-287. U.S. Department of Energy, Washington, D.C.

United States Department of Agriculture (1936-1990) Agricultural Statistics, 1936, 1952, 1966, 1975 and 1990. U. S. Government Printing Office, Washington, D.C.

Weisberg S (1980) Applied Linear Regression. John Wiley \& Sons, New York, 283 pp. 